\title{
Analysis of the Effect of Packaging Creativity, Packaging Effectiveness and Brand Trust on Interest in Purchasing SME Products in East Java
}

\author{
Novan Andrianto ${ }^{1 *}$ Rahayu Arya Shintawati ${ }^{1}$ \\ ${ }^{1}$ Universitas Dinamika, Indonesia \\ *Corresponding author.Email: novan@dinamika.ac.id
}

\begin{abstract}
This study aims to analyze the effect of packaging creativity, packaging effectiveness and brand trust on SME product buying interest in East Java Province. The population targeted in this study were students in East Java Province who were active in management and business study programs in 2020. The number of samples in this study was determined as many as 200 people who were taken with a sampling technique in the form of purposive sampling. Data obtained through the distribution of questionnaires. The data analysis technique used in this study is multiple regression analysis. This research is considered important because the findings produced in this study are expected to be the basis for the formulation of strategies for increasing the sales performance of products produced by SMEs. The novelty of this research lies in the brand trust variable. Brand trust is chosen as a factor influencing buying interest because brand trust is the willingness of consumers to buy a particular brand with the assumption that the brand is able to meet what is expected by consumers. This research succeeded in proving that the creativity of packaging, the effectiveness of packaging and brand trust have a significant influence on the buying interest of SME products in East Java Province.
\end{abstract}

Keywords: Packaging Creativity; Packaging Effectiveness; Brand Trust, Purchase Interest; Small and Medium Enterprises.

\section{INTRODUCTION}

In the current global era, various types of products have developed in Indonesia. The development of a variety of products requires business people to compete with each other to excel in market competition and maintain andeven increase buying interest from consumers[1]. Most companies overcome this by providing and improving facilities and infrastructure with the help of technology[2]. These efforts are aimed at providing satisfaction to consumers[3]. On the other hand, the competition not only provides opportunities but also challenges[2]. The challenge is to require every business person to scramble and even survive in terms of market share control so that the right marketing strategy is needed to make products that meet consumer expectations[4]. After that, the company as a product maker must be able to deliver products that have been made to potential consumers or target markets so that consumers know the existence of the company and its products[5].

If the delivery of information is appropriate, itcan attract consumers to buy[6]. To increase consumer buying interest, companies must be able to face and overcome various threats that exist so that companies can still survive in competition in the current global era[7]. This can be anticipated through packaging. Packaging aims for various things including creating brand awareness, conveying brand excellence, creating brand perception, attracting interest in brands, and influencing consumers 
to buy[8]. These goals are efforts by companies to improve consumer response, which ends at the level of sales in the longrun[9].

Besides, the packaging is also used as a form of the promise given by companies to consumers[10]. This means that the packaging is used as a means of delivering information related to the product[11]. In general, packaging aims to change or even influence consumer behavior[12]. Consumer buying interest is influenced by the packaging creativity factor[13]. This packaging creativity as a change in the attitude of the audience towards the product being packaged[14], [15]. The changes are ad- likability and product likability[16].

Ad-likability is the level of interest in packaging, whileproduct likabilityis the level of interest in the product. These two things have an impact on consumer purchase preferences and interests. The effectiveness of packaging can also affect buying interest. The effectiveness of these consumers is determined through packagingcreativity[17].

This is because as a stimulus to consumer interest and consumer memory[18]. However, the creativity of packaging can also interfere with attention to the brand if done excessively[16]. On the other hand, buying interest can also be influenced by the brand trust. This is because they are carriers of the company's image. The brand is used as the identity of certain products, so it looks different from others. Brand trust is the willingness of consumers to buy certain products assuming that the product can meet what is expected.

This research was conducted on management study program students in East Java Province. The object of the research is determined based on the problem being studied. In addition, the number of management study program students is considered high with the adult category. Based on these explanations, research is needed on "The Effect of Packaging Creativity, Packaging Effectiveness and Brand Trust on Interest in Buying SME Products in East Java Province". The novelty of this research lies in the brand trust variable. Brand trust is chosen as a factor influencing buying interest because brand trust is the willingness of consumers to buy a particular brand with the assumption that the brand is able to meet what is expected by consumers.

\section{LITERATURE REVIEW AND HYPOTHESES}

\subsection{Packaging Creativity}

Creativity is defined as a creative idea in solving a problem. In this case, it must be accompanied by something new or commonly referred to as originality[17]. The originality must be adjusted appropriately and beneficial. This can be better if it collaborated with broad community approval[18]. Packaging creativity as an important aspect for the company, because it is the key to attracting consumer interest[11]. The packaging is considered creative if it is made without imitating from people, has a meaning that is meaningful, and can cause emotional feelings.

Creativity can be seen in several aspects. These aspects are not widely found, are different from others, and are original. The packaging is said to be creative if it is different from another packaging in general, so that if the packaging of a product has ever been found or even encountered, then the product cannot compete with competitors, moreover, it cannot attract consumers' interest[18]. Thus it can be understood that packaging creativity is a very important thing to pay attention to, implement and develop well to compete with competitors and attract consumers to buy. The ways that can be done in this regard include, easy to remember, simple, and able to influence the emotional sense of consumers[16].

\subsection{Packaging Effectiveness}

The packaging is said to be effective if it can understand the needs and desires of consumers, able to communicate appropriately, and refer to the behavior that must becarried out by consumers[15]. Besides, if the packaging can attract consumers' interest, it is easyto remember or even influence consumers to buy. The effectiveness of packaging can be seen in two things. First, the communication effect of packaging which includes knowledge, awareness, and preferences. Second, the effect on the level ofsales.

The effectiveness of packaging consists of various dimensions including (1) attention (attention), this includes size, color, layout, and typography, (2) understanding (cognitive response), namely consumer knowledge and behavior, (3) attitude towards packaging (advertising attitude/advertising liking), namely the attitude of agreeing or disagreeing with the consumer, (4) attitude towards the brand (brand attitude), namely consumer perception of the product and (5) purchase intention is the willingness of consumers to buy theproduct. 


\section{Procedia Business and Financial Technology}

Proceedings of the 2nd International Conference on Business and M anagement of T echnology (ICO N BM T 2020) - Part 2

\subsection{Brand Trust}

Trust arises based on the needs and desires of certain parties that have been met by other parties[19]. If a certain party feels trust in the other party, then an argument arises that what is expected can be fulfilled without even feeling disappointed. In this case, it can be understood that brand trust is the willingness of consumers to believe in certain brands with the assumption that the brand can fulfill whatis expected and provide satisfaction. Therefore, trust in a brand can be realized if the product can meet or even exceed what is expected by consumers to express satisfaction to consumers[4]. This satisfaction arises after the consumer uses or consumes the product.

Consumers who already believe in a product, certainly do not turn to the products of other companies, so that it can be understood that the brand has a very important role. On this basis, every company must be able to determine the brand precisely to realize consumer confidence that the products offered can meet what is expected. Trust arises through brand promises. If the promise is not fulfilled, then the trust can be reduced or even lost, thus also impacting consumer buying interest. This is because consumers have feelings of worry about the brand, especially if the brand has not been recognized. Brand trust is influenced by three factors namely the brand itself, company personality, and consumerpersonality.

\subsection{Purchase Interest}

Products that have been used or consumed by consumers are products that are decided to be purchased. Consumer purchasing decisions are influenced by various factors that are valued on the product. One such factor is the benefit of the costs incurred. If the benefits obtained by consumers exceed the costs incurred, of course, consumers are interested in buying.

If the benefits obtained by consumers are not proportional to the costs incurred, then not interested in buying. Interest is interpreted as a person's sense of interest in a particular thing with the assumption that it is very important. Buying interest is also defined as the motivation of consumers to make purchases or even repurchases. In addition, buying interest is also understood as a mental impetus in consumers to make certain product purchases. Based on this description, it can be concluded that buying interest is a sense of willingness or desire for someone to buy a particular product, which arises from the urge to reflect. In buying interest, several things must be considered, among others (1) interest is considered as an incentive to take certain actions. (2) interest as a form of how much courage someone has to experiment, (3) interest shows how much effort has been done by someone, and (4) interest has an impact on consumer behavior in thefuture.

\subsection{Hyphotheses}

One of the most important marketing elements for companies and consumers is the packaging. The intended packaging is packaging creativity. Moreover, packaging creativity is a major part of packaging effectiveness, which has an impact on consumers' interests and memories. The packaging is said to be effective if it can understand consumer needs, communicate benefits appropriately, and refer to the attitudes that must be carried out by consumers. Therefore, the better the effectiveness of packaging, the consumer buying interest will increase. Besides, consumer buying interest is also influenced by brand trust, so the stronger brand trust, the consumer buying interest is increasing. The hypothesis in research is adjusted to the theory and thought framework that has been explained. The hypotheses in this study are as follows:

H1 : The packaging creativity influences the buying interest of SME products in East Java in management study program students in East Java Province.

$\mathrm{H} 2$ : The effectiveness of packaging affects the interest in buying SME products in East Java in management study program students in East Java Province.

H3 : Brand trust influences the buying interest of SME products in East Java in management study program students in East Java Province.

\section{RESEARCH METHOD}

\subsection{Research Design}

This research is survey research. Survey research is research conducted to find out the truth of a problem that occurs without finding out the factors that cause it. Besides, survey research was conducted to obtain the opinions of each individual. Therefore, the data in this study are primary because they are obtained directly from respondents by giving a set of questions.

\subsection{Population, Samples and Sampling Techniques}

The population selected in this study were all active 
students of management study programs in East Java Province 2019/2020 school year. The sample selected in this study were active students of management studies in East Java Province who use or consume SME products. In taking samples, the technique used is purposivesampling.

The characteristics determined are active students of management studies in East Java Province. In determining the number of samples, based on previous research recommendations that range from 100 to 200 respondents, so in this study taken as many as 200 respondents. But before searching for data from 200 respondents, research instruments must first be given to 30 respondents to conduct a validity test and a reliability test of the research instrument so that the data obtained can be further analyzed. When viewed by region, respondents in this study are prioritized in the Surabaya, Sidoarjo, Pasuruan, and Probolinggo regions. Respondents were determined based on the area so that this research could produce findings and interpret data analysis that could be generalized to represent the study population. Data was collected through a questionnaire (questionnaire) distributed to respondents. The instruments in this study were prepared using a Likert scale. This study consists of three independent variables, namely packaging creativity (X1), the effectiveness of packaging (X2), and brand trust (X3) with one dependent variable, namely buying interest (Y). The data analysis technique used in this study is the multiple regression analysis. The multiple regression analysis was carried out through the Structural Equation Model Partial Least Square using SmartPLS 3.

\subsection{Test Instrument}

Before being used in research, a questionnaire was first tested. Test the instrument. The instrument trials were used to find out whether the statement items contained in the questionnaire produced correct data because this had an impact on the quality of the research conducted. The questionnaire for the trial of this instrument was given to 30 respondents. The instrument trials consisted of two namely validity and reliability tests. A validity test is used to know that the statement items in the questionnaire can explain the problem being studied. A validity test is done through a construct validity test using Confirmatory Factor Analysis (CFA). The validity test is determined by the loading factor value of $\geq 0.50$. If the loading factor value is $\geq 0.50$, then the statement items in this study are valid. The reliability test comes from the word reliability which means that trustworthiness, reliability, consistency, accuracy, and others. In this case, it can be understood that the reliability test is used to find out that the respondent's answer in the statement item is trustworthy (reliable). The reliability test is determined by Cronbach's Alpha value. If the Cronbach's Alpha value> 0.60 or even close to 1 , then the respondent's answer to the statement item is declaredreliable.

\subsection{Hypothesis Testing}

Data analysis in this study uses PLS (Partial Least Squares) which is a method of Structural Equation Model (SEM). The initial step taken in PLS is to test the outer model, namely the validity and reliability tests. Validity test in PLS is calculated using convergent validity and discriminant validity. Indicator is said to be valid if it has an outer loadings value $>0.5$ and has the largest cross loadings value on the variable. Reliability test is performed using composite reliability, where data is said to be reliable if it has a composite reliability value $>0.7$. Inner model calculations are performed to calculate the feasibility of the research model. Testing is done by looking at the value of $\mathrm{R}^{2}$ with a predictive relevance measure $\mathrm{Q}^{2}$. The model is said to be relevance if the $\mathrm{Q}^{2}$ result is greater than 0 . The final step in PLS is hypothesis testing. Hypothesis testing is done by comparing the value of $\mathrm{t}$-stat with the value of $\mathrm{t}$ - table at an error rate of $\square=5 \%$ or 1.96. Hypotheses can be accepted if the t-value is greater than thet-tablevalue.

\section{RESULTS AND DISCUSSION}

The relationship between constructs and indicators must be assessed in the measurement model, which consists of two phases, namely the assessment of convergent validity and discriminant validity. Convergent validity is performed by evaluating indicators of validity, construct reliability, and extracted average variance (AVE). Indicator of validity can be seen from the load factor value of more than 0.5 with a statistical value of more than 2.0 , so it can be assessed valid. It can be seen from the results of the study that all indicators in this study can be declared valid because they meet the requirements for evaluating indicators of validity.

All values of the loading factors of the indicators used for the measurement of the variables studied in this study are worth more than 0.5 as well as the results of the test of the 
significance of the factor loading with $\mathrm{t}$ statistics. So it can be interpreted that the indicators in this study have good validity because the loading factor is the correlation between this indicator and its construct. All loading factors have a $\mathrm{t}$-value of more than 2.0 , so it is clear that all indicators in this study can be said to have significant validity. Further measurements of the convergent validity built on reliability by assessing the reliability of Cronbach's composite or alpha output. Ideal reliability has a combined reliability value of more than 0.70 and AVE value of more than 0.50 . all constructs in this study can be said to be reliable because they have a composite value of more than 0.70 and a AVE value of more than 0.50. Evaluation of the measurement model with discriminant validity is processed in two stages, namely measuring the value of cross-loadings and comparing the square of the correlation between constructs with the value of AVE or the correlation between constructs with roots of AVE.

The criteria in crossloading are emphasized on each indicator that measures the construct must have a higher correlation with the construct itself compared to other constructs. Each indicator in this study correlates higher with each construct than the other constructs, so it can be concluded that the indicators in this study have relatively good discriminant discriminant validity values. After that, it is continued with a comparative test between correlation with AVE. Likewise, the maximum correlation value of the other variables in this study seems to be smaller than the AVE value of each. In this way a conclusion can be drawn that this study has good discriminant validity. The next stage in this research, after testing the measurement model has been fulfilled, then the structural model testing can be done. This test includes evaluating the significance of the path link and $\mathrm{R}^{2}$ values. Significant path relationship is seen in the influence of packaging creativity (X1), the effectiveness of packaging (X2), and brand trust (X3) toward one dependent variable, namely buying interest $(\mathrm{Y})$. This is because the value of the statistical $t$ coefficient is more than 2.0. It can be concluded that all hypotheses of direct influence between variables in this study proved to be significant. Figure 1 illustrates the external model test, which shows that the value of the loading factor for all indicators of this study is more than 0.7 .

\section{CONCLUSION}

Based on the results of research that consistently supports all assumptions or hypotheses proposed in this study, it can be concluded that packaging creativity (X1), the effectiveness of packaging (X2), and brand trust (X3) have a positive and significant impact on buying interest $(\mathrm{Y})$. This research has proven that partially packaging creativity (X1) has a positive and significant influence on buying interest. This research also managed to reveal that the effectiveness of packaging (X2) also had a positive and significant influence on buying interest $(\mathrm{Y})$. In addition, this research also proves that brand trust (X3) partially has a positive and significant influence on buying interest $(\mathrm{Y})$. From this conclusion, SME needs to pay attention to packaging creativity, effectiveness of packaging and brand trust in order to create buying interest of the customers.

\section{ACKNOWLEDGEMENT}

The author would like to thank RISTEKDIKTI Indonesia for providing support to this research in the form of research grants. The author also thanks the editors and reviewers for the correction and valuable input for the perfection of this paper. The author also thanks all parties who have supported the completion of this research.

\section{REFERENCES}

[1] N. Souiden, N. Amara, and W. Chaouali, "Optimal Image Mix Cues and Their Impacts on Consumers' Purchase Intention," J. Retail. Consum. Serv., vol. 54, no. January 2019, p. 102011, 2020, doi: 10.1016/j.jretconser.2019.102011.

[2] Q. Shang, J. Jin, and J. Qiu, "Utilitarian or Hedonic: Event-Related Potential Evidence of Purchase Intention Bias During Online Shopping Festivals," Neurosci. Lett., no. November, p. 134665, 2019, doi: 10.1016/j.neulet.2019.134665.

[3] C. Mcclure and Y. Seock, "The role of Involvement: Investigating the Effect of Brand's Social Media Pages on Consumer Purchase Intention," J. Retail. Consum. Serv., vol. 53, no. October 2019, p. 101975, 2020, doi: 10.1016/j.jretconser.2019.101975.

[4] H. Chae, S. Kim, J. Lee, and K. Park, "Impact of 


\section{Procedia Business and Financial Technology}

Proceedings of the 2nd International Conference on Business and M anagement of T echnology (ICO N BM T 2020) - Part 2

Product Characteristics of Limited Edition Shoes on Perceived Value, Brand Trust, and Purchase Intention; Focused on the Scarcity Message Frequency," J. Bus. Res., no. November 2018, pp. 0-1, 2018, doi: 10.1016/j.jbusres.2019.11.040.

[5] A. Vahdat, A. Alizadeh, S. Quach, and N. Hamelin, "Would You Like to Shop Via Mobile App Technology? The Technology Acceptance Model, Social Factors and Purchase Intention," no. January, pp. 1-10, 2020, doi: 10.1016/j.ausmj.2020.01.002.

[6] J. Fan, D. Ni, and X. Fang, "Liability Cost Sharing, Product Quality Choice, and Coordination in TwoEchelon Supply Chains," Eur. J. Oper. Res., 2020, doi: 10.1016/j.ejor.2020.01.003.

[7] X. Wen and T. Siqin, "How Do Product Quality Uncertainties Affect the Sharing Economy Platforms with Risk Considerations ? A MeanVariance Analysis," Int. J. Prod. Econ., p. 107544, 2019, doi: 10.1016/j.ijpe.2019.107544.

[8] L. Wu, H. Liu, and K. Su, "Exploring the Dual Effect of Effectuation on New Product Development Speed and Quality," J. Bus. Res., vol. 106, no. 135, pp. 8293, 2020, doi: 10.1016/j.jbusres.2019.09.016.

[9] L. M. Granero, "Strategic product variety and quality choice $九$," vol. 182, pp. 10-14, 2019, doi: 10.1016/j.econlet.2019.05.033.

[10] P. Piveteau and G. Smagghue, "Estimating fi rm product quality using trade data $\boldsymbol{\sim}$, , J. Int. Econ., vol. 118, pp. 217-232, 2019, doi: 10.1016/j.jinteco.2019.02.005.

[11] A. Y. A. Fianto, "The Antecedents of Purchase Decision for Hijab Fashion Products," Manajemen, vol. 12, no. 1, pp. 154-165, 2020.
[12] A. Y. A. Fianto, "Satifaction As Intervening For The Antecedents Of Intention To Revisit: Marine Tourism Context In East Java," Relasi, vol. 16, no. 1, pp. 179-207, 2020.

[13] R. Santoso, R. Shinta, and A. Y. A. Fianto, "Pengaruh Bauran Pemasaran Jasa terhadap Keputusan Berkunjung ke Wisata Bahari Jawa Timur," Manaj. dan Bisnis, vol. 4, pp. 1-14, 2019.

[14] S. Lauwrentius, "Penciptaan City Branding melalui Maskot sebagai Upaya untuk Mempromosikan Kabupaten Lumajang," Unpublished Undergraduate Thesis, Visual Communication Design, 2015.

[15] A. Marzuqi, "Penciptaan Motif Batik sebagai Ikon Kabupaten Lumajang," Institut Bisnis dan Informatika Stikom Surabaya, 2015.

[16] E. Y. Ikawira and A. Y. A. Fianto, "Penciptaan Buku Ilustrasi Legenda Reog Sebagai Upaya Mengenalkan Budaya Lokal kepada AnakAnak," Art Nouv., vol. 3, no. 1, 2014.

[17] A. Jafar, A. Y. A. Fianto, and S. P. Yosep, "Penciptaan Buku Ilustrasi Permainan Tradisional Sebagai Upaya Pelestarian Warisan Budaya Lokal," Art Nouv., vol. 3, no. 1, 2014.

[18] R. D. Pinasti, A. Y. A. Fianto, and W. Hidayat, "Penciptaan Buku Komik Sebagai Upaya Pengenalan Permainan Tradisional Kepada Remaja," Art Nouv., vol. 4, no. 1, 2015.

[19] H. Song, J. Wang, and H. Han, "Effect of Image, Satisfaction, Trust, Love, and Respect on Loyalty Formation for Name-Brand Coffee Shops," Int. J. Hosp. Manag., vol. 79, no. June 2018, pp. 50-59, 2019, doi: 10.1016/j.ijhm.2018.12.011 